\title{
SOCIO-PHILOSOPHICAL ANALYSIS OF THE PHENOMENON OF INFORMATION SOCIETY
}

\author{
Yushkevych Yu. S.
}

\section{INTRODUCTION}

The rapid development of science and technology at the end of the last century led to a fundamental transformation of modern society and a transition to a qualitatively new stage in world history, which is characterized by the emergence of an innovative society in comparison with the industrial type. Its main features are, firstly, the completion of urbanization, a decrease in the rate of population concentration in megacities, a reduction in the share of the industrial sector of the economy and a corresponding quantitative increase in human capital that is involved in the services sector, de-industrialization, and secondly, the development of information and communication technologies and their increase role in the life of modern man.

It should be noted that the latest scientific discourse is represented by a large number of publications that are devoted to social transformations in modern developed countries. However, it is characterized by the absence of a universally recognized concept, which would fully reflect all the changes that occur in various spheres of public life in their relationship and historical perspective. The most famous researchers of this problem are D. Bell, who proposed the theory of "post-industrial society", which is an analogue of the concept of a "new industrial society" by J. Galbraith, as well as Y. Masuda, F. Machlup, M. Porat, T. Umesao, who developed the theory of "information society", M. Castells - "network society", A. Etzioni - "active society", V. Inozemtsev - "post-economic society", R. Presthus - "organizational society", P. Drucker, R. Lane, N. Stehr, G. Bechmann - "knowledge society" and "smart-society". Thus, the modern scientific space is characterized by the mosaic plurality of local conceptualizations, the absence of a grand narrative, as well as syncretism - the attributive identity of various models of modern society and conventionality - the fuzziness of authorship of existing theories ${ }^{1}$.

Therefore, the identification of the content of the priority concept of the "information society", the elements perceived in it, its internal structure and the system of which it acts as a component, necessitates its comparison with

Тузовский И.Д. Исторические обстоятельства, обусловившие синкретизм и конвенционализм современного состояния теории информационного общества. Вестник Челябинской государственной академии культуры и искусств. 2015. № 3 (43). С. 7. 
other concepts, in particular, "post-industrial society", "knowledge society" and "smart society", which is the goal of our research.

\section{The phenomenon "information society": conceptual analysis}

A comparative analysis of the existing concepts of the modern stage of development of society necessitates the following. In the conditions of terminological improvisation and the practice of disparate analytics of certain aspects of social structures of both the information society and similar forms of social reality, the most productive is a methodological approach that excludes an eclectic combination of modern research of the functioning of various forms of societies, and is aimed at identifying common features of transformational changes in general and systematization of specific attributes inherent in the multidimensional social plane of modernity.

As a result of a comparative analysis of various definitions of the concepts of "post-industrial society" and "information society", the three most common positions regarding the relationship of these phenomena were identified. In the framework of the first approach, the "information society" is considered as a specific branch of "post-industrialism". V. L. Inozemtsev notes that the theory of "post-industrial society" is a metatheory in relation to "information society". $\mathrm{He}$ notes that post-industrialists defined technological progress and the codification of theoretical knowledge as determinants of the formation of a new society. This naturally led to the emergence of a theory within which these factors were considered prevailing. Thus, the concept of the information society, which is a component of post-industrial theory, according to the author, is able to concretize and deepen our understanding of the modern world ${ }^{2}$.

Another way of comparing these phenomena is their complete identification, which has a realization in two forms. Firstly, it is an automatic synonymization within the framework of which there is no differentiation, not only of the concepts of "post-industrial society" and "information society", but also of the "knowledge society" and "smart society", which is due to the desire to only outline the current state of development of world civilization. Secondly, it is an intentional emphasis on their equivalence. The fundamental argument of representatives of this point of view, in particular M. Connors, is the impossibility of achieving postindustrialism outside of a cardinal axiological reorientation to postmaterial, informational wealth, which, in his opinion, looks quite utopian ${ }^{3}$.

\footnotetext{
${ }^{2}$ Иноземцев В.Л. Современное постиндустриальное общество: природа, противоречия, перспективы. М.: Логос, 2000. С. 15-16.

${ }^{3}$ Connors M. The race to the intelligent state: towards the global information economy of 2005. Oxford, UK, Cambridge Mass: Blackwell Business, 1993.
} 
Fairly thorough, in our opinion, is the third position. So, the information society is defined either as a phase of development of a post-industrial society, or as a result of the development of human civilization, the next higher stage compared to previous ones, such as industrial and post-industrial societies. D. Bell notes that the terms knowledge society, information society or professional society are in a certain way suitable for reflecting the characteristic aspects of modern social being. However, the "speculative concept" that he formulated with the prefix "post", which is a "post-industrial society," better expresses a feeling of life in the intermediate time. He notes that the post-industrial society is developing in the direction of the information society or the knowledge society where the constitutive principle social organization becomes theoretical knowledge ${ }^{4}$.

Equally varied is the ratio in another pair of concepts "information society" - "knowledge society". It should be noted that, in our opinion, the quite natural result of the development of the concept of the information society is the awareness of the greater importance of knowledge than information. This led to the interpretation of the modern stage of social development as a knowledge society. So, the identification of the concepts of "information society" and "knowledge society" is due to the substantiation of the determining role of knowledge in improving the living standards of both an individual person and the whole society. This knowledge is acquired as a result of free access to information and the ability to process $i^{5}$. According to this point of view, an inextricable link is between the information society and the knowledge society. They exist simultaneously, while the information society is a society in which theoretical knowledge acts as a catalyst for its further development. G. Bechmann notes that society can be defined as informational if its basic conditions for reproduction depend on scientific knowledge 6 .

There is another way of comparing the phenomena of "information society" and "knowledge society". So, according to some scholars, the concept of the information society represents the technological dimension of modern transformations, in contrast to the theory of the knowledge society, which considers the socio-cultural, economic, political and legal aspects of these changes. Moreover, the theory of the knowledge society more fully

4 Белл Д. Прихід постіндустріального суспільства. Сучасна зарубіжна соиіальна філософія. К.: Либідь, 1996. С. 230-231.

5 Залізняк В.А., Ліпкан В.А. Систематизація інформаційного законодавства України: монографія. К.: ФОП О.С. Ліпкан, 2012. С. 253.

6 Бехманн Г. Общество знания - трансформация современных обществ. Концепция “общества знания” в современной социальной теории. М.: ИНИОН РАН, 2010. С. 63. 
reveals the complexity and dynamism of these processes ${ }^{7}$. Therefore, these concepts cannot be considered equivalent.

If we consider these types of society as stages of further development, it is necessary to define its direction. The most common is the following point of view. The information society is gradually transforming into a knowledge society. In particular, the UNESCO world report "Towards knowledge societies" indicates that the global information society will only make sense if it becomes a tool to achieve the higher and more desirable goal of which is the creation of a global knowledge society. This ensures the ability to find, transform, produce, disseminate and use information to obtain and apply the knowledge necessary for human development ${ }^{8}$. In addition, in the conceptual sense, the condition for the emergence of the theory of the knowledge society is considered to be the distinction between the concepts of "information" and "knowledge", as a result of which the knowledge society began to be considered as a new stage in the development of the information society. The driving force behind the development of this society is a person who is capable of mastering information flows, using modern information technologies and creating intelligent products based on this 9 .

The main argument of representatives of a radically different position regarding the sequence of occurrence of these two types of society is based on chronological indicators that demonstrate the primacy of the formation of the theory of the knowledge society, which dates back to the 1940s. This point of view is presented in the studies of P. Drucker and F. Machlup. These scientists define the conceptual framework of the paradigm of the knowledge society, which includes the key concept - the "knowledge society", as well as the concepts of "knowledge labor", "knowledge worker", "knowledge economy" and "knowledge industry". The theoretical development of the concept of the information society was started by T. Umesao and M. Igarashi, who proposed the terms "information industry" and "information society", which was later presented in the works of Y. Masuda, K. Kohyma and Y. Hayashi, but this only happened in the $1960 \mathrm{~s}^{10}$.

It should be noted that the definition and comparison of the concepts of "knowledge" and "information" contributes to a better understanding of the essence of the above phenomena. In this context, in our opinion, it is useful to

${ }^{7}$ Хан А.В. На пути к обществам знаний. Наука в информационном обществе. СПб., 2004. С. 22-26.

${ }^{8}$ Всемирный доклад ЮНЕСКО: К обществам знания. Париж: ЮНЕСКО, 2005. С. 29.

9 Климова А.Б. От информационного общества - к обществу знания. Дискуссия: журнал научных публикащий. 2016. № 7 (70). С. 78.

${ }_{10}$ Карпов А.О. Общество знаний: знание vs информация. Философские науки. 2017. № 12. C. 21-23. 
compare the views of F. Machlup and T. Umesao - two core narratives which are the basis of the concepts of the knowledge society and the information society. F. Machlup almost identifies the terms "knowledge" and "information", considering the first of them to be a priority for characterizing a new social state ${ }^{11}$, in contrast to T. Umesao, who uses the word "information" to mean "everything that can be conveyed using symbols", "a system of signs that are transmitted from person to person as a whole"12. Thus, in the first narrative, the system of knowledge production plays a constitutive role, while in the second - the system of translating the sign. Thus, despite the presence of a significant number of common conceptual components, these positions are antagonistic.

N. Stehr and U. Ufer offer their own definition of knowledge as "ability to act", which ensures the interconnection of the actions of individual actors with the social environment, which distinguishes it from information. The main feature of the world of knowledge, in their opinion, is the distribution and transfer of knowledge: knowledge producers differ from those who consume it, this necessitates its transfer - the presence of a global knowledge society involves the transfer of knowledge ${ }^{13}$. N. Stehr notes that knowledge is not only a constitutive feature of the modern economy, but also acts as the organizing principle of the whole society. We build our whole life on the basis of knowledge. Interesting in this context is the author's emphasis on the relativity of this knowledge. He notes that scientific knowledge has a special status in modern society not because of absolute truth and objectivity or an adequate reflection of reality, but because this form of knowledge to a greater extent than any other creates new possibilities of action that are assimilated and used by individuals, firms and by states. The result of the dissemination of this knowledge is not only unpredictable risks and complete uncertainty, but also the creation of a "liberating action potential"14.

Interesting is the position of A. A. Karpov. So, he emphasizes that knowledge is not information and cannot be determined through it, and information, in turn, is not knowledge and is not capable of becoming it, although it participates in its creation. An attempt to identify these phenomena through their signedness, in his opinion, is false because it is only a form of

11 Machlup F. The production and distributation of knowledge in the United States. Princeton: Princeton university press, 1972.

12 Умесао Т. Теория информационной индустрии - рассвет грядущей эпохи эктодермальной индустрии. Информация и циивилиация: собрание починений. Т. 14. Токио: Тюокоронся, 1991. С. 25-27.

13 Штер Н., Уфер У. Глобальные миры знания. Концепция “общества знания” 8 современной социальной теории. М.: ИНИОН РАН, 2010. С. 179.

${ }^{14}$ Штер Н. Мир из знания. Социологический журнал. 2002. № 2. С. 31-34. 
expression. In fact, the "biota" unites knowledge and information. It is a condition of their existence, it gives birth and stores knowledge and perceives information. Moreover, the author's understanding of "thinking biota" goes beyond the human race and provides for a wider biological approach ${ }^{15}$.

In our opinion, "knowledge" cannot be equated with "information". Moreover, none of these concepts is subordinate to the other. Knowledge is what we gain in the process of mental activity; it is the result of knowledge. Information, based on the etymology of this word, is an explanation, interpretation, presentation, acquaintance with something, namely with knowledge. The signedness of these phenomena, in our opinion, is that rather distinguish than unite it. Knowledge as such does not require any kind of formal image with the help of a sign, the need to translate this knowledge, which in this context already acquires the status of information, determines the operation of signs. Therefore, we consider it necessary to agree with the statement of F. Machlup, who notes that "not all knowledge can be called information". At the same time, in our opinion, the first part of the statement is debatable "any information in the most common sense of the word is knowledge"16. The definition of information as a form of knowledge is incorrect. For example, genetics, where information is the genetic code of a particular organism, makes it impossible to have knowledge as the content of this information due to the lack of a reflection process. Therefore, we are critical of the above position within which knowledge and information are combined on the basis of their beingness at any biological level, even at the level of a unicellular organism, to which the presence of mental activity is attributed.

The information-knowledge approach is proposed in the scientific discourse to indicate the equivalence of the information and knowledge paradigms of modern social development. In the framework of this approach, the dialectic of the interaction of information and knowledge in the "information-man-knowledge" system is substantiated. However, in our opinion, this concept requires some clarification. If we take into account that information is a form of translation whose content is knowledge, then the "process of converting information into knowledge" should include not only the transition from information to knowledge, but also, on the contrary, the presence of knowledge that must be transmitted first of all. This indicates a more complex relationship of these concepts, which is implemented in the system "knowledge-informationknowledge". This system clearly reflects its cyclic and progressive - spiral

${ }_{15}$ Карпов А.О. Общество знаний: знание vs информация. Философские науки. 2017. № 12. С. 27.

16 Machlup F. The production and distributation of knowledge in the United States. Princeton: Princeton university press, 1972. P. 15. 
character and implicitly contains an anthropological dimension. In addition, an appeal to other equally important theories, one of which will be considered below, would necessitate the formulation of a too complicated terminological construct, which, from our point of view, is not advisable.

Finally, we want to focus on another, the most trendy, definition of the modern stage of development of world civilization - a smart-society. The concept of "smart" was first used in management as a system of criteria for the quality of goals that a manager sets for an organization. It is an abbreviation consisting of the first letters of words: specific - a clear and simple formulation of the goal that must be achieved; measurable - the presence of a system of indicators with the help of which the degree of achievement of the goal, its effectiveness is defined; achievable - identification of mechanisms for achieving the goal that are adequate to the capabilities of the performers; relevant - substantiation of compliance of the goal with realities - needs, resources, time; time-bound - correlation with a specific period at the end of which the goal should be achieved. The author of this term is P. Drucker, who proposed the "smart" methodology in his work "Management Practice" in 1954. This was due to the need to identify ways that can ensure the growth of economic efficiency and optimization of company management.

The transfer of the above principles of smart management to the social plane led to the formation of a new vision for building social reality and contributed to the emergence of the concept of smart-society. The progressiveness of this society is based primarily on efficiency, which necessitates the use of appropriate technologies for organizing the life of an individual and society as a whole.

In the framework of the most common conceptual approach, it is noted that smart-society is a logical continuation of previous forms of historical evolution of the modern world. This symbolizes the transition from the information society, which is characterized by the post-industrial level of its development, to the knowledge society ${ }^{17}$. The basis for the development of smart-society are smart-technologies - modern information technologies, characterized by universality and interdisciplinarity, which are aimed at improving the quality of human life. A person, in turn, acts as the bearer of "smart consciousness", which is realized in the appropriate behavior effective interaction between people, as well as people and technologies ${ }^{18}$.

17 Воронкова В.Г., Романенко Т.П., Андрюкайтене Р. Генеза від інформаційного суспільства до “smart-суспільства" в контексті історичної еволюції сучасного світу: теоретико-концептуальний контекст. Гілея: науковий вісник. 2017. Вип. 116 (1). С. 128.

${ }_{18}$ Ардашкин И.Б. Смарт-общество как этап развития новых технологий для общества или как новый этап социального развития (прогресса): к постановке проблемы. Вестник Томского государственного университета. Философия. Социология. Политология. 2017. № 38. C. 35 . 
P. Drucker notes that with the transition to a "knowledge society", a person becomes a key figure in this new world, the role of an "educated person" significantly increases ${ }^{19}$. M. Castells, adhering to the same point of view, notes that in a "network society" the professional structure of employment is being improved due to the growing importance of education as a component of qualification that is necessary to carry out information work. But at the same time, he emphasizes that the low quality of education or the inability of the educational system to provide a new type of qualification, which is necessary for the latest professional structure, creates the opposite effect ${ }^{20}$.

Professor J. Ramallah proposed stem-education (science, technology, engineering, mathematics) in the USA in 2001. She considers it the most relevant educational model that can satisfy the needs of an innovative society. At STEM, science and mathematics are the foundation for technology and engineering. Science and mathematics are prevailing in understanding the universe, while engineering and technology are the means of interaction between man and the universe. STEM promotes the harmonious interweaving of these elements of human activity and understanding in the educational plane. The stem-oriented approach to education, from the point of view of its supporters, provides the formation of the ability to generate new ideas, the development of intellectual flexibility and critical thinking. But, in our opinion, the formation of these competencies is somewhat beyond the scope of the proposed "quadrivium format".

As P. Drucker notes, a modern person should still be comprehensively developed. She must be able to project her knowledge into the present, moreover, make them work for the future. He notes that in the knowledge society there is no "queen of sciences" - all areas of knowledge are equally valuable. As the great medieval philosopher St. Bonaventure said, they still lead to the truth. But the effectiveness of education, in particular humanitarian, whose main task is to create a world of discourse without which civilization is impossible, depends on further integration into the "world of knowledge" $"$. In this context, M. Castells emphasizes that education should be a process in which, first of all, a person gains the ability to constantly change the complex of her own skills that are necessary to fulfill the tasks facing her, referring to sources that contain relevant innovative knowledge ${ }^{22}$. Actually, we are talking about the implementation of the principle of "learning throughout life".

\footnotetext{
${ }^{19}$ Друкер П.Ф. Энциклопедия менеджмента. М.: Издательский дом “Вильямс”, 2004. С. 348.

${ }^{20}$ Кастельс М. Информационная эпохи: экономика, общество и культура. М.: ГУ ВШЭ, 2000. C. 264.

${ }^{21}$ Друкер П.Ф. Энциклопедия менеджмента. С. 347-349, 354-355.

${ }^{22}$ Кастельс М. Информационная эпохи: экономика, общество и культура. С. 497.
} 
In addition, creativity is the main indicator that is prevailing in identifying an individual as an "educated person". It is not an innate genius, but is a tendency that can be developed throughout life. For example, the ability to creatively solve problem situations, unconventionality in interpersonal communication, and an innovative approach to the surrounding subject environment. A creative person can see a problem that requires attention where others do not see it; can determine the goal and its corresponding tasks, and can also offer the most optimal, innovative, risk-free way to solve it among the maximum number of alternative options.

Therefore, it is quite logical to reorient from stem-education to steameducation, which is not limited to the components indicated above, but assumes their association around the A component (art). The idea of adding art to STEM has recently become increasingly popular. At the same time, "A" in STEAM represents not only art, but a wider subject circle, which includes disciplines of the social and humanitarian block. It should be noted that the orientation of education only on science, engineering and mathematics outside the participation of Arts-disciplines can lead to the complete destruction of any creativity. Only the unity of the science and the humanitarian approach can support innovators in today's complex world.

\section{Virtual reality as a phenomenon of the information society}

The problems of the information society, which increasingly cover all spheres of modern life, have become the subject of study of the humanities. The eternal theme of human life, and especially the sphere of its existence that is traditionally covered by the general concept of "inner world", deserves special attention. When it comes to the modern person in the information society, the question of the factors that determine this inner world and the effect on the worldview of a person of such a phenomenon of the contemporary sociocultural space as "virtual reality" is logical.

One of the most famous theorists of the information society, E. Toffler, considering the changes in the human community from the standpoint of cultural changes, noted that humanity is faced with deep social shifts of social tectonic plates and the transformation of creative activity. E. Toffler owns the statement that we live in a world of "blip culture" (reflected, on-screen, flickering culture), what is now called "virtual reality". Instead of using the ready-made ideal model of reality that reigned in the industrial era, a person must reproduce it again and again in the information age. This kind of creativity opens up great opportunities for the development of individuality, the demassification of personality and culture. A person ceases to be a 
standard, easily controlled robot, as he was imagined during the "second wave" $" 23$.

Extremely important from the worldview and anthropological point of view is the statement of $\mathrm{E}$. Toffler that thinking with images turns into thinking with reflected (virtual) images.

This thought of a famous scientist actualizes the need to analyze the phenomenon of virtual reality not only from the point of view of its content, but also to search for mechanisms of influence of such a peculiar reality on a person's worldview, in the consciousness of which not only an integral picture of the world is formed, but also a "virtual worldview" is formed, which complements it.

By its content, a worldview is a holistic entity in which general ideas about the world, principles, laws and assessments of a particular era are integrated in the human mind. Such representations strive for complete integrity; it include in their structure rationally grounded true knowledge of the world, certain irrational assumptions, assessments, beliefs. The main issue of worldview regarding the relationship "man - the world" in the modern information society is complicated by another reality - virtual. And naturally in this connection the question arises: is there any specific world behind this virtual reality that can be designated as virtual and does it not distort the true picture of the world? The answer to this question should first be sought in the content of these concepts.

The term "virtual" has its own history. In the Middle Ages, through this category, scholastics sought to answer the question of how absolute entities are realized in certain temporal and individual phenomena and events. Thus, using the concept of virtuality, T. Aquinas solved one of the key problems of medieval philosophy - how there are realities of different levels, for example, a thinking soul, an animal soul, a vegetable soul ${ }^{24}$. Much later, the concept of virtuality acquires a new breath after the concept of "virtual reality" begins to be used. This term originated at the Massachusetts Institute of Technology in the late 70 s of the twentieth century. This term was proposed to refer to threedimensional macro-models of reality, which are created using a computer that conveys the effect of the complete presence of a person in it ${ }^{25}$.

Postmodernism, which is a specific worldview of the modern information society, offers one of the ways to consider virtual reality and define its specificity. So, in particular, the analysis of the category of virtual reality is carried out by means of postmodern philosophical ideas that use the theory of

${ }^{23}$ Тоффлер Э. Третья волна. М.: Издательство АСТ, 1999. С. 10.

${ }^{24}$ Фома Аквинский. Сумма теологии. Антология мировой философии. 1969. С. 848.

${ }^{25}$ Hammet F. Virtual reality. New York: Straus Ed., 1993. 213 p. 
simulacra. This theory was actively developed in the framework of the postmodern paradigm by its famous representatives G. Deleuze, J. Baudrillard and others. In the framework of this theory, a simulacrum is defined as a sign that acquires its own existence, creating its own reality and ceasing to be essentially a sign after that. It is such a peculiar body, but it is virtual. That is, a simulacrum is real like any body, which acts as a referent in this situation, is real but it is virtually real. A simulacrum begins where the similarity ends; virtual reality as the space of simulacra begins in the same place. They acquire their virtual being, in relation to which the real reality is the source of its existence. Thus, the ontological status of virtual reality can be described as an organized space of simulacra - special objects, "alienated signs", which, in contrast to signs-copies, record not similarity, but difference with reference reality.

It should be noted that summarizing the existing definitions of the concept of "virtual reality", we share the point of view of scientists who distinguish the following as its main properties. Procreation - virtual reality exists due to the activity of some other reality external to it. Relevance - it exists only "here and now", and only as long as the reality that generates it is active. Autonomy - it exists according to its laws, in its time and space. Interactivity - it can interact with all other realities, including the one that generates it, being ontologically independent of the ${ }^{26}$.

One of the most relevant is the question of how virtual reality, which is organized in the space of virtual objects (including simulacra), affects the real being of a person. It is known that every person is a "man of his time". The worldview of a certain culture of a certain time reigns in it. The universal essence of human being is not a constant. It is dynamic and mobile. Thus, a change in the general content of a worldview in a person's consciousness occurs due to the spread and assimilation by him of individual experience, which is partially absorbed by the space of objects of virtual reality. In this situation, virtual reality is part of the environment in which a person can act as its participant. Often a person is the creator of a whole artificial world, which is created by technical means and transmitted through the sensations of man. That is, it can be an active subject of imitative influence, when the real reality may not be so attractive, in contrast to the modeled one. The peculiarity of the worldview is that a person has always sought to equip the world around her, adapting to it through her own worlds that she creates, which, in essence, are indisputably virtual. Their virtuality is due to many reasons, including all kinds of "idols" of human cognition, when the result of reflecting reality is a simulation through the creation in the human mind of a picture of the world that has little in common with the real world.

${ }^{26}$ Носов Н.А. Виртуальная реальность: философские и психологические аспекты. М., 1997. $187 \mathrm{c}$. 
However, the real, full awareness of the role of virtual reality in human life began with the full-scale introduction of electronic technologies. "Virtual reality, encompassing more and more new spheres of human life, is becoming a symbol of the reality of the information society... it satisfies the need of people in communication, information exchange, in creative implementation... it is a "parallel world" of human being... a world of creative imagination, which is created in the process of modeling potential situations of development of the real world"27. Thus, the information society fully contributed to the establishment of virtual reality as a socially significant phenomenon. This necessitated the formation of the concept of "virtual worldview", which makes it possible to characterize a modern worldview, taking into account the phenomenon of virtual reality as an integral and essential component of the "man-world" system. That is, considering the "man-world" relationship as the main issue of the worldview, it should be borne in mind that in the era of the formation and development of the information society, the phenomenon of virtual reality is immanent in the structure of modern social being, which is necessarily woven into the structure of this relationship. Unlike actual reality, which is characterized by integrity, stability and completeness, virtual reality is a source of diversity, embodies the possibilities of creative, generating activity.

There is no doubt that virtual objects (including simulacra) in various forms were always present in individual and social life. But only now they are becoming inalienable characteristics, largely determining the peculiar face of the information society, which created technical opportunities for activating resources that were not previously used in the framework of the previous (modern) sociocultural paradigm.

When dramatic changes take place in the sociocultural space of the modern information society in a historically condensed framework, in the eyes of one generation, then such changes affect the individual's worldview in two ways. On the one hand, under the influence of a globalized mass media system, computerization, when digital technologies generate the wonderful world of virtual reality, there is a noticeable unification, mystification and simulation of mass consciousness, which creates simulacra and illusions in people. In this regard, A. Toffler noted that a new generation of third-wave culture feels great among all this bombardment with signals: a nine-second news clip interrupted by thirty seconds of advertising, a fragment of a song or poetry, a headline, a media clip, a caricature, a collage, a computer printout. Insatiable readers of

${ }^{27}$ Кивлюк О.П., Мордоус І.О. Гра як феномен філософської антропології в контексті віртуалізації суспільства. Освітній дискурс. Гуманітарні науки : збірник наукових пращь. 2018. Вип. 7 (8). С. 25-26. 
advertisements of a large amount of information learned in a short time how to follow certain trends without really delving into their essence, while they integrate all these virtual images into something whole... In such a situation, instead of just getting the mental model of reality we are familiar with we are forced to invent it again and again. It's quite difficult, but it leads to greater personality, demassification of personality and culture ${ }^{28}$. Indeed, the growing development of virtualization of the information sphere creates the prerequisites for significant changes in both social consciousness as a whole and the worldview of an individual. Information is being transformed from a means to a goal, standardizes the behavior, interests and inclinations of people. At the same time, the negative consequences of excessive human enthusiasm for the power of information and its virtual capabilities are growing. On the other hand, along with these changes, an extremely opposite trend is observed. A modern person has an unprecedented opportunity to fully manifest and realize his personality, which largely affects his worldview.

It should be noted that the informational "pressure" on a person increases every year, the availability of large amounts of information requires time and effort to comprehend them. And this requires appropriate education, improvement of intellectual functions and tools that would allow to process such information.

\section{CONCLUSIONS}

The explication of the conceptual sphere of the philosophical discourse of the phenomenon of "information society" allows us to conclude that the existing concepts of modern development of society to a certain extent complement each other. They focus on the more significant aspect within each of them; therefore, the study of the concept of "information society" through its comparison with the concepts of "post-industrial society", "knowledge society", "smart-society" is justified. By systematizing the content features of the concepts that we are considering, the following should be noted. The information society represents a new stage in the development of mankind, which is characterized by the presence of high-level information and communication technologies and a developed information infrastructure. This ensures free access of any person to information resources and contributes to the increasing role of the production of information as a form of translation, the content of which is knowledge. This happens against the background of the transformation of all spheres of society and the implementation of the principles of efficiency and optimization of the organization of life of an individual and society as a whole.

\footnotetext{
${ }^{28}$ Тоффлер Э. Третья волна. С. 182.
} 
In modern society, a person, in particular his inner world - worldview, should be the subject of special research. The expansion of opportunities to take advantage of the information society will appear only with an adequate understanding of human potential. Thus, it is necessary to understand the significance of free time as an indicator of the wealth of the information society, and not just an understanding of wealth as the consumption of material goods. It is also necessary to realize that the reason for the virtualization of the modern information society is the objective need for the transition of information technology to a qualitatively new level, which would contribute to the development of the inherent human need for creativity, create a new reality, including such worlds in relation to which it will feel like a creator.

\section{SUMMARY}

The article deals with the content of the concept of "information society", the elements perceived in it, its internal structure and the system component of which it is, by comparing it with the concepts of "postindustrial society", "knowledge society", "smart-society"; the content of the phenomenon of virtual reality in the modern information society and to identify the mechanisms of its influence on a person's worldview. It was concluded that the information society is a new stage in the development of mankind, which is characterized by the presence of high-level information and communication technologies and a developed information infrastructure, which ensures that any person has free access to information resources and contributes to the increase in the role of production of information as a form of translation whose content is knowledge; this happens against the background of the transformation of all spheres of society and the implementation of the principles of efficiency and optimization of the organization of being both of an individual and society as a whole. It was concluded that man has always sought to adapt to the world, creating his own images, which are inherently virtual. Transformations taking place in the structure of the modern worldview occur not only as a result of human-world interaction, but also are influenced by virtual reality as special social relations and specific virtual objects that are actively developed in the modern information society. The growing development of the virtualization of the information sphere creates prerequisites for changes both in the social consciousness in general and in the virtual worldview, which interprets the world from the standpoint of a person as a subject of virtual reality. 


\section{REFERENCES}

1. Тузовский И.Д. Исторические обстоятельства, обусловившие синкретизм и конвенционализм современного состояния теории информационного общества. Вестник Челябинской государственной академии культуры и искусств. 2015. № 3 (43). С. 7.

2. Иноземцев В.Л. Современное постиндустриальное общество: природа, противоречия, перспективы. М.: Логос, 2000. С. 15-16.

3. Connors M. The race to the intelligent state: towards the global information economy of 2005. Oxford, UK, Cambridge Mass: Blackwell Business, 1993.

4. Белл Д. Прихід постіндустріального суспільства. Сучасна зарубіжна соиіальна філософія. К.: Либідь, 1996. С. 230-231.

5. Залізняк В.А., Ліпкан В.А. Систематизація інформаційного законодавства України: монографія. К.: ФОП О. С. Ліпкан, 2012. С. 253.

6. Бехманн Г. Общество знания - трансформация современных обществ. Концепиия "общества знания" в современной соииальной теории. М.: ИНИОН РАН, 2010. С. 63.

7. Хан А.В. На пути к обществам знаний. Наука в информащионном обществе. СПб., 2004. С. 22-26.

8. Всемирный доклад ЮНЕСКО: К обществам знания. Париж: ЮНЕСКО, 2005. С. 29.

9. Климова А.Б. От информационного общества - к обществу знания. Дискуссия: журнал научных публикаџий. 2016. № 7 (70). С. 78.

10. Карпов А.О. Общество знаний: знание vs информация. Философские науки. 2017. № 12. С. 21-23.

11. Machlup F. The production and distributation of knowledge in the United States. Princeton: Princeton university press, 1972.

12. Умесао Т. Теория информационной индустрии - рассвет грядущей эпохи эктодермальной индустрии. Информация и цивилизация: собрание починений. Т. 14. Токио: Тюокоронся, 1991. С. 25-27.

13. Штер Н., Уфер У. Глобальные миры знания. Концепция “общества знания” в современной социальной теории. М.: ИНИОН PAH, 2010. C. 179.

14. Штер Н. Мир из знания. Социологический журнал. 2002. № 2. C. 31-34.

15. Карпов А.О. Общество знаний: знание vs информация. Философские науки. 2017. № 12. С. 27.

16. Machlup F. The production and distributation of knowledge in the United States. Princeton: Princeton university press, 1972. P. 15.

17. Пархоменко О.В., Пархоменко В.Д. Інформаційно-знаннєвий підхід до визначення парадигми соціально-економічного розвитку. Наука, технологіï, інноваиії. 2017. № 1. С. 15. 
18. Воронкова В.Г., Романенко Т.П., Андрюкайтене Р. Генеза від інформаційного суспільства до "smart-суспільства" в контексті історичної еволюції сучасного світу: теоретико-концептуальний контекст. Гілея: науковий вісник. 2017. Вип.116 (1). С. 128.

19. Ардашкин И.Б. Смарт-общество как этап развития новых технологий для общества или как новый этап социального развития (прогресса): к постановке проблемы. Вестник Томского государственного университета. Философия. Социология. Политология. 2017. № 38. С. 35.

20. Друкер П. Ф. Энциклопедия менеджмента. М.: Издательский дом “Вильямс", 2004. С. 348.

21. Кастельс М. Информационная эпохи: экономика, общество и культура. М.: ГУ ВШЭ, 2000. С. 264.

22. Друкер П.Ф. Энциклопедия менеджмента. С. 347-349, 354-355.

23. Кастельс М. Информационная эпохи: экономика, общество и культура. С. 497.

24. Тоффлер Э. Третья волна. М.: Издательство АСТ, 1999. С. 10.

25. Фома Аквинский. Сумма теологии. Антология мировой философии. 1969. С. 848.

26. Hammet F. Virtual reality. New York: Straus Ed., 1993. 213 p.

27. Носов Н.А. Виртуальная реальность: философские и психологические аспекты. М., 1997. 187 с.

28. Кивлюк О.П., Мордоус I.О. Гра як феномен філософської антропології в контексті віртуалізації суспільства. Освітній дискурс. Гуманітарні науки : збірник наукових пращь. 2018. Вип. 7 (8). С. 25-26.

29. Тоффлер Э. Третья волна. С. 182.

Information about the author: Yushkevych Yu. S.,

Candidate of Philosophical Sciences, Senior Lecturer at the Department of Philosophy, History and Political Science, Odessa National Economic University 8, Preobrazhenskaya str., Odessa, 65082, Ukraine 